Ruiz Rosendo, L. \& Persaud, C. (2016). Interpreting in conflict zones throughout history. Linguistica Antverpiensia, New Series: Themes in Translation Studies, 15, 1-35.

\title{
Interpreters and interpreting in conflict zones and scenarios: A historical perspective
}

\section{Lucía Ruiz Rosendo}

University of Geneva, Switzerland

Lucia.Ruiz@unige.ch

\section{Clementina Persaud}

University Pablo de Olavide, Spain

clempersaud@yahoo.com

This article presents an overview of interpreting in conflict zones and scenarios in different periods of history as represented in the papers included in the special issue. Conflict between parties with different cultural and linguistic backgrounds is pervasive in human history and has always involved interpreters in the sense of intercultural and linguistic mediators. Although interpreting became highly professionalized from the second half of the twentieth century, language brokering in conflict zones is still an unregulated occupation mainly pursued by untrained interpreters. Furthermore, there is a lack of recognition of the specific role that interpreters in conflict situations play. In spite of an increasing awareness of the role of interpreters in conflict zones and an expanding scholarly literature on the subject, we believe that more monographs adopting a historical standpoint are needed. The aim of this special volume is to shed light on the characteristics, ideology, status, neutrality, occupation, role in the different stages of the conflict, training issues, and working practices and procedures of interpreters in conflict zones.

\section{Interpreting in conflict zones}

Conflict, and therefore language brokering in conflict zones, has been pervasive throughout human history. Conflict arises in response to a threat, whether as a result of clashes between peoples and nations or in the midst of a community. And when one of the parties does not speak the language of the other, some type of language mediation is necessary. Despite the frequent invisibility of interpreters in the historical record and the mutability of the interpreter's status or role, the need for and importance of interpreters is undeniable (Baigorri, 2014a, 2014b; Campbell, 2001; Delisle \& Woodsworth, 2012; Mairs, 2011; Roland, 1999). Many 
multilingual historical events, such as the signing of treaties, peace accords and military and trade negotiations, would have necessarily required language intermediaries for their implementation, whether or not the presence or qualifications of the interpreter is mentioned in the historical record. In this connection, it is important to note that the importance of reliable language brokers has been long recognized in at least some contexts (Cáceres-Würsig, 2012; Galán, 2011; Gehman, 1914; Hermann, $1956 / 2002$; Roland, 1999), as demonstrated by the provision of professional training for language mediators, even though such training is rarely referenced in the literature (Baigorri, 2015; Cáceres-Würsig, 2012; Child, 2010; Roland, 1999). Indeed, in discussing the role and the presence of interpreters in different settings, Mairs (2011) stresses the importance of noting those occasions on which interpreters were not involved, as they were more than likely exceptions to the general rule.

Among the possible reasons for the invisibility of the interpreter in the historical record are: (1) the primacy of the written word over the spoken word, which means that translators' activities are more likely to have been chronicled than those of interpreters; (2) social status and gender, as the individuals recruited as language brokers were usually enslaved women, members of sub-castes, prisoners of war, displaced individuals, or victims of circumstance, and (3) the fact that historians cannot be expected to include every single available detail in their accounts of important historical events, meaning that the participation of individuals in secondary roles, such as interpreters or language brokers, may go unrecorded (Delisle \& Woodsworth, 2012; Roland, 1999).

Furthermore, even on those occasions when their presence is mentioned, interpreters working in conflict zones are rarely referred to by name or singled out for detailed description or comment. As a result, very few interpreters have been named or included in history books, although a few records of their participation and work do exist. The scarce information available on these interpreters derives from a variety of sources that generally focus on commercial, political, historical and military events, rather than on interpreting as a professional activity. This oversight is starkly described by Roland (1999:7), who refers to interpreters as "the missing link". This trend began to move in the reverse direction, however, at the end of the twentieth century and beginning of the twenty-first century, when scholarly interest in interpreting in conflict zones increased and began to be studied from different angles, as evidenced by the work of authors such as Andres (2012), Baigorri (2014a), Delisle \& Woodsworth (2012), Gaiba (1998) and Roland (1999). In fact, the seminal works on the history of interpreting by Baigorri (2015), Delisle and Woodsworth (2012), Takeda and Baigorri (2016) and Roland (1999) provide us with an explicit weft of the role played by interpreters in different settings throughout history. 


\section{Interpreters in conflict}

In the past decade, various authors have agreed on the need to examine the role played by translators and interpreters during conflicts in different regions (cf. Baker, 2010a, 2010b; Collier, 2010; Dragovic-Drouet, 2007; Footitt \& Kelly, 2012; Inghilleri, 2008, 2009; Juvinall, 2013; Ozawa, 2008; Palmer, 2007; Rafael, 2007; Stahuljak, 2000, 2009; Takeda, 2009; Vieira, 2014). Analysing interpreting in conflict zones is not straightforward, however, partly due to the fact that the relations between the parties involved in conflict tend to be complicated. Interpreters may potentially play an important role in intelligence work performed before and during a given conflict (Moser-Mercer \& Bali, 2008). Not all interpreters working in conflicts are professionals, however (Baker, 2010b; Inghilleri, 2010); nor does the fact that an interpreter is working in a conflict setting necessarily mean that he or she has professional experience as an interpreter or a linguistic mediator. This is the case with local interpreters, who are generally recruited because they know the local language and one or more local dialects as well as the language of the foreign army, or of the international agencies or organisations that provide humanitarian aid and organise peacekeeping work (Allen, 2012; Baigorri, 2011; Moser-Mercer $\&$ Bali, 2008). Since these individuals are not hired on the basis of prior training or experience as interpreters, they may not start out with the necessary skills to interpret adequately.

Allen (2012) identifies three categories of war interpretersmilitary linguists, contract interpreters and humanitarian interpreters - and describes their distinct features. For Allen, the military linguist is a member of an established system that has access to plentiful financial resources for training staff to speak the different languages required in conflict settings throughout the world. Kelly and Baker (2013), however, highlight the fact that translators and interpreters do not occupy a clearly distinguished role within the armed forces. The term "interpreter" is used in the military to indicate a high level of language proficiency, whereas the term "military interpreter" could include all specialist language tasks, not necessarily only interpreting and/or language mediation. This fact demonstrates the difficulty of pinpointing the precise status and role that ought to be played by the interpreting professional.

Contract interpreters are professionals who provide the bulk of the interpretation services in wars and armed conflicts when the level of violence is lowered (Kelly \& Baker, 2013). They work in different settings, using not only linguistic skills but also "soft skills" or cross-cultural competencies that are considered important assets in war and peacekeeping contexts (Baker, 2010b; Bos \& Soeters, 2006; Ingold, 2014; Lewis, 2012; Vieira, 2014).

The last group-interpreters working on the ground with international aid and news organizations - are less well known, but very much in demand because their abilities and experience are essential to the 
parties seeking their services. Their services may also be required by relief agencies in disaster zones where there has been an earthquake or an incident involving mass casualties.

There is some doubt, however, as to whether the reality of the situation is as clear-cut as Allen's classification would seem to imply, and one could debate whether these categories exist as such at present.

\section{Interpreting in conflict zones throughout history}

In spite of the increasing scholarly interest in the interpreting that takes place in conflict zones, few studies have examined and/or compared the interpreter's status at different moments in history. The historiography of a profession not only narrates the passage of time; it has an impact that goes beyond a mere date- and fact-finding exercise. Observing and analysing the role played by members of any profession through the lens of time allows us to understand the complexity of that role in context and to view the situation under study more objectively. Analysis of the extant historical documents regarding interpreters in conflict zones provides a wealth of information on interpreters' behaviour and allows for more precise assessment of the situation within a well-defined temporal and situational context.

For these reasons, we felt that particular attention ought to be given to understanding and describing language mediators in conflict-related settings, especially given the current focus on the role and place of the interpreters in conflict zones. This focus is due not only to the hazards and dangers they encounter in the performance of their assignments, but also to the many other challenges they face related to ethics, neutrality, allegiances, and status. We also believe that this historical review can help us learn from the past by providing insights into how certain problems were resolved and helping us to predict possible difficulties and therefore possibly avoid them. Such a review could also help to identify possible solutions that may be extrapolated to the situations faced today by war interpreters.

In recent years, media portrayals of language mediators in war zones - including reports of violence against them - have highlighted the paucity of war-related training provided for these individuals; on many occasions, they are not provided the same protections offered to accredited interpreters or to members of the military. Despite this neglect, they are frequently required to perform duties that go far beyond their role and status, two concepts which are elusive in their own right. It is important to note that these interpreters' extremely fragile position is a fairly recent development; taking a historical perspective allows us to contrast their lack of military training and protection with that of their counterparts in previous conflicts whose nature was different from those of the present day. 
The attention that interpreting in conflicts is receiving from the media and the scholarly community at the present time is such that it might seem that interpreting in conflict zones is a fairly new phenomenon. This is manifestly not the case, however, as stated above. For this reason, this special issue reaches back in time to take a retrospective view of interpreting in conflict settings, with the aim of examining the situation of language brokers at different times and in diverse places and situations. This analysis seeks to identify changes in the status, role and recognition of the interpreter over the centuries. In the light of the general absence of interpreters and interpreting from historical records, we take a multifaceted approach to describing general and specific cases of interpreters and interpreting in their historical contexts. In order to achieve this goal, the following questions were posed to the contributors to this issue:

- What has been the role of interpreters in conflict zones and in conflict situations in certain episodes of history concerning working practices and procedures?

- What are the policies and norms that have regulated the role of conflict interpreters throughout history?

- What are the ethics underlying the work of conflict interpreters in specific periods of history?

- What has been the role of the interpreter in recent conflicts?

- How could the profile and status, neutrality, identity and ideology of the interpreter working in conflict settings be described? Have these concepts changed throughout history? Is there a clear definition of these concepts or do they require a more detailed analysis?

- What role have interpreters played in the different stages of conflicts (conflict settlement, conflict transformation and conflict resolution (Brahm, 2003))?

- What is the role of the interpreter in protracted conflicts?

- What are the present and future directions that research on this topic might take concerning current and future practices and training that might enhance the status of these interpreters?

This special issue of Linguistica Antverpiensia brings together scholars delineating the research field of interpreting in conflict zones, studying its relationship with history, and trying to answer the research questions listed above. This collection of articles casts a look back at history, specifically at people who have served as linguistic and cultural mediators in conflict zones. 


\subsection{Antiquity}

The first references to the existence of interpreters appear around 2600 BCE in Ancient Sumer, where a list of words in cuneiform script on a clay tablet found at Tell Abü Şalābīkh, Southern Iraq ${ }^{1}$, details a registry of different professions recorded in hierarchical order. The literal expression "eme-bal", "to interpret", and "to turn" ("bal") "language" ("eme"), are clearly referred to in this list ${ }^{2}$ (see Bellos, 2011; Chrobak, 2013). Moreover, the interpreter's position in this ranking (eleventh out of eighteen) seems to indicate that interpreters held quite a high position in Ancient Sumer. It is also worth noting that, in this period, agreements between different peoples were signed in different languages, a fact that proves the participation of language brokers in such exchanges (Chrobak, 2013).

Records from Ancient Egypt also confirm the presence of interpreters in that civilisation. On the walls of the tombs of the princes of Elephantine, on Qubbet el-Hawa, a hill near Aswan, one encounters the term $j m y--r(A)$ aw ("overseer/chief of interpreters"). Here we find a depiction of the dealings of the Egyptians of the Sixth Dynasty with Nubia. Interestingly enough, this event coincides in time with the abandoning of nomadism by the Egyptians, which resulted in a sedentary lifestyle and the development of a large administrative infrastructure. This change in lifestyle also meant that Egyptians maintained peaceful contact with foreign peoples from the beginning of the establishment of their empire (Galán, 1995, 2011). As a result, interpreters were hired by the court to aid in brokering trade relations and military expeditions, which led to their being considered one of the seven social classes of the Egyptian population, a fact that not only acknowledges their existence as professionals but also illustrates their position in society. Despite this recognition of the profession, interpreters were considered of low rank in Ancient Egypt, and their status was similar to that of a seaman or a merchant. Consequently, they were not much respected socially, despite possessing valuable language skills (Kurz, 1985). It must be stated that despite a preference for noble trainees, most interpreters in this period were of lower-class birth, slaves or freed men (Roland, 1999), although nomarchs - supreme chiefs and supervisors of the local administration (nomes), high-ranking officials in the public administration, and often bilingual-enjoyed a higher status than interpreters. Despite the generally low social status of interpreters and the fact that the Egyptians usually regarded other nations and their languages as barbarian, Egyptians were aware of the impossibility of ignoring foreign languages when engaging in trade or military operations. They were thus compelled to work with interpreters.

Another record attesting to the existence of interpreters in Ancient Egypt is the depiction of a guide-interpreter leading a group of foreigners before the king in the Amarna tombs on the east bank of the Nile. In fact, in Amarna, on tomb no. 8 (i.e. Tutu's ${ }^{3}$ tomb), an inscription explains how 
the chief of the foreign delegation addressed the king through his interpreter. Both Andres (2012) and Galán (1995) describe how the interpreters represented on the tomb can be clearly distinguished, as each one is portrayed as two people - as was the custom in Egyptian hieroglyphs - probably to show that they had to carry out a task that required them to work into two languages and for two different parties.

In this vein, the tomb biography of Harkhuf ${ }^{4}$ deserves a special mention as it is considered the first recorded evidence of the exchanges that took place between the Egyptian Empire and other peoples. It is important to exercise caution when drawing conclusions about inscriptions from this period, however, because the term "interpreter" was potentially used to designate anyone who spoke foreign languages rather than in the modern sense of a member of a profession. In fact, many scribes were also translators or interpreters, even though they had received no formal training to carry out their job. Despite the lack of training, scribes were acknowledged professionally. Tadmor (1991) confirms the fact that one special term was used to refer to bilingual scribes_- se-pi-ru," borrowed from Aramaic - while another, related, term - "targummanu"-was used to refer to the interpreter or the person who translated oral communications (Hutton \& Marzouk, 2012; Pöchhacker, 2004; Tadmor, 1991). We therefore find two terms for two different professional activities, although there was no clear separation of tasks in professional practice nor identification as such by users.

As time passed and the importance of language brokering increased, the custom of selecting young men and training them to become interpreters arose. Pharaoh Psamtik $\mathrm{II}^{5}$, aware of the increasing need for language brokers, decided to create a caste of brand-new interpreters when he took the decision to send a large group of young men to Greece to learn the language of the land (Baigorri, 2015). This pioneering practice of training language experts was also followed by other important leaders such as Alexander the Great and Quintus Sertorius ${ }^{6}$ (Roland, 1999).

Moving forward in time to Carthage, historians mention two events related to interpreting at war (Gehman, 1914; Taulbee, 1998). Gehman (1914) discusses the communication problems Carthaginians had with their troops, which were composed of mercenaries of different origins who spoke many languages, including Libyan, Iberian, Celtic, Latin, Greek and Punic. This meant they had to rely on interpreters to relay the commanders' messages, sometimes having to communicate orders up to five times due to the multilingual composition of their army. Many communication problems, with concomitant serious consequences, arose as a result of using amateur linguists as language brokers. In fact, in 220-216 BCE Polybius $^{7}$ describes the Carthaginian troops as originating from Iberia, Celtic lands, Liguria, the Balearic Islands, Greece and other regions. Polybius tells the story of Gesco, a Carthaginian general and government emissary, who was appointed to negotiate and mediate between the troops and the Senate with the help of interpreters, in order to resolve a dispute 
about payments to the soldiers. His efforts were hindered by Spendius and Mathos, two deserters and rebel leaders who convinced the Libyan mercenaries that Gesco was dealing with them in bad faith. Autaritus, the leader of the Gallic mercenaries in the Carthaginian army during the First Punic War, argued that Gesco and those who had been seized with him should be put to death. Since Autaritus spoke Phoenician, a language that most of the men could understand, he was able to convince most of them. Even if some men from other nationalities did defend Gesco, they were not understood because each spoke in their own language. Gesco was eventually tortured and killed. The inclusion of a detailed report of these events, describing the eventual capture, sentencing and execution of Gesco, highlights the significance of the episode.

The second documented event, also narrated by Polybius, occurred during the Second Punic War, when Hanno the Great waged war in Sicily. Sunianto, a very influential citizen of Carthage, was elected mediator for communications between Hanno, the Carthaginian commander, and Hiero II of Syracuse. In the letters in Greek sent by Sunianto to Hiero, Sunianto informed Hiero of the approach of Hanno's armies. The message was intercepted and he was accused of treason by Hanno. As a consequence of this affair, the Carthaginian senate ruled that only official interpreters would be used for communications with the enemy thereafter, and that no other citizen of Carthage would be allowed to learn Greek (Gehman, 1914; Hultsch, 1889/2012; Roland, 1999). These detailed, documented events clearly demonstrate that interpreters played an important role in the military.

Turning our attention to Ancient Greece, we see that it, like previous kingdoms and empires, required the services of language brokers to ensure adequate communication between peoples or parties within the empire itself who did not share a common language. The difficulty in clarifying the role of the interpreter in Ancient Greece is at least partially due to the ambiguity of the terms used to refer to language brokers. The term

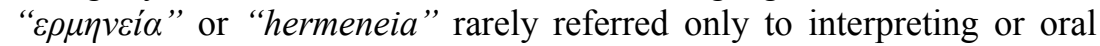
translation activities; it was also applied to middlemen who carried out other tasks of a commercial or general negotiating nature (Mairs, 2011). This suggests that the interpreter was not only a language broker, but also a commercial intermediary, or even played both roles at the same time. This fact is further supported by a document from the Ptolemaic Dynasty which mentions Apollonios, "the interpreter of the Trogodytes." The confusion is compounded by the fact that the "Hermeneus" (i.e., interpreter) often performed an additional regulatory function as an "Agoranomos", who was akin to a public notary as well as being in charge of supervising every aspect of a marketplace.

The Greeks did not rely on interpreters solely for commercial transactions. Like the Carthaginians, their armies included recruits of many different nationalities. Proof of this can be found in Xenophon's Anabasis, which is an account of the march of the ten-thousand-soldier army to the 
Battle of Cunaxa and back to Greece (401-399 BCE). This document mentions more than once that Cyrus the Younger used interpreters and that the presence of interpreters avoided disaster. Not only are interpreters in general mentioned on several occasions, but the name of one of these interpreters, Pigres, is given, as well as that of one of Cyrus's officers, Glus (Hogdman, 1915), who was sent to congratulate Meno the Thesallian by Cyrus. Even the commanders of monolingual armies always had interpreters with them. In Plutarch we find that Alexander the Great's expeditions to Central Asia required interpreters of different languages, including Persian, Hycarnian, Sogdian and Indian. It seems clear from these accounts that interpreters were present in the ancient Greek army as well as in the armies of their adversaries.

The great demand for linguists in commercial and military domains is confirmed by the fact that it was common for the Greeks to be accompanied by interpreters when travelling outside their country, whether for commercial or military reasons. The importance of language brokers is further confirmed by the fact that there seem to have been some individuals who studied languages in order to become fully-fledged interpreters, while other individuals who studied languages did not do so with the aim of becoming an interpreter but nevertheless ended up working in the profession for other reasons. Examples of these individuals include Themistocles, who studied Persian, and Ovid, the poet, who knew Getic and Sarmatian (Gehman, 1914). Another key point to remember is that some interpreters grew up in a bilingual environment or had exogamous parents, which paved the way for careers as interpreters.

For evidence of the polyglot nature of the Roman Empire, we need only consider its geographic extension. Educated Romans from the Republic onwards were required to master Latin, as a precondition to participation in the world's government, and Greek, in order to participate in the empire's cultural life. The Romans, like the Greeks before them, showed little interest in learning the languages of the so-called barbarian tribes and would do so only for practical reasons (Rochette, 1996).

Caesar's use of interpreters is mentioned in the Commentaries on the Gallic War, or Bellum Gallicum; ${ }^{10}$ it can also be presumed that other commanders in the Roman army had language brokers available to help them communicate with the peoples and dignitaries of the lands they conquered. Interpreters were present not only in the military but also in diplomatic assemblies and meetings, where their presence was accepted without question (Torregaray, 2009).

In Rome, the Latin term "interpretes" was used to refer to both translators and interpreters in the sense of intermediaries who brokered the conclusion of a contract between two parties (Tănase \& Muscalu, 2013). Pöchhacker (2004) believes that the reason for this double meaning could be that the term is derived from "partes" or "pretium", which is what adds the meaning of "middleman", "intermediary" or "commercial go-between" to the description. In addition, these two Latin terms refer to an individual 
who explains the meaning or makes sense of what others have difficulty understanding.

Interpreters in Roman times were full-time professionals, and were paid for their services by the national treasury. In spite of this, interpreters were not acknowledged as a professional body in the army during Roman times, and they would have to wait until the 5 th century for this recognition. Spies, who also tended to be bilingual, were referred to by the same term used for interpreters (i.e., "interpretes"), therefore occasionally making it difficult to differentiate between spies and interpreters in the historical record (Cáceres-Würsig, 2012). This was probably because spies were not the only language experts hired by the military. These individuals were also usually appointed to sensitive missions; they were mostly natives of barbarian countries, but were also highly Romanised. Being natives of the regions where they operated as spies made it easier for them to get into enemy territory and obtain information that was essential to the Roman army (Tănase \& Muscalu, 2013).

Peretz (2006) offers a clear description of the status of the military interpreter in Roman times. Despite the low rank and position of interpreters, interpreting was still considered an important profession. Although Roman interpreters worked full time and were considered faithful to their patrons, they did not hold life-long commissions, but rather formed temporary relationships with their clients. They were even considered new Roman citizens, but there is no evidence whether they organised as a group or not.

Not all interpreters were at the same administrative level; there was a hierarchy among them. At the lowest level, they were legionary soldiers, and had the right to a double allowance of food in addition to their pay ("stipendium") if their services were considered satisfactory. At a higher level, their position was more advantageous, as they received a "salarium," or annual sum, which covered expenses. The military interpreter was also given freedom of action while on mission and was exempted from heavy duties, in contrast to other active soldiers, which probably shows that she or he was an "immunis", that is, an individual who was free from paying taxes or from public obligation (Frank, 1936). Military interpreters could also be relieved of the prohibition on commercial activity, meaning that they could profit from involvement with other populations and thus obtain an added source of income. It is also important to mention that Roman interpreters had diplomatic immunity in those cases where they were members of an embassy to the enemy (Peretz, 2006).

The fragmented Western Roman Empire fell in $476 \mathrm{CE}$ with the deposition of Romulus Augustulus, though its Eastern counterpart survived another millennium. Although Latin was the main medium of communication immediately after the Western Roman provinces fell, its use diminished considerably by the end of the 6th century, when it lost its status as an official language; it was considered a dead language by the 7th century. From this period onwards, Romance languages started to thrive 
and develop. However, the disappearance of Latin was short-lived. In the 8th century, it was once again reinstated as the prestige language of "administration, international relations, education, science, theology and the intelligentsia" (Blumenthal \& Kahane, 1979, p. 187), a status it would maintain until the 12th century, when vernaculars were used for courtly entertainment.

In the former Eastern Roman Provinces, the enviable location of Constantinople and the policies implemented by Constantine led to a 12thcentury Byzantium characterised by its multilingual society and an empire where the thousands of foreigners residing in it were awarded trading privileges and tax exemptions. By then Constantinople had become a cosmopolitan city. Leo Tuscus, ${ }^{11}$ from Pisa, was the Byzantine Emperor Manuel Komnenos' official interpreter and his existence is mentioned circa 1149 CE (Haskins, 1918). Interpreters were also required for the Imperial Guard as its troops were mainly Turks and Varangians (Brand, 1968).

This multilingual environment meant that many linguistic needs had to be addressed and, consequently, Barbarian Academies were created by the Byzantines. These academies became sources for interpreters and guides (Diener, 1938). Although these professionals hardly ever attained membership of the upper echelons of the civil service, there were a few exceptions, such as those individuals who attained the position of Great Logothete, a public official who played a very important role in the Byzantine administration as the comptroller of finances. When Byzantium was taken over in 1453 by the Ottomans, Arabic became the official language of the empire.

\subsection{The Middle Ages: The Crusades}

After the fall of the Roman Empire, more languages were spoken in Europe than in today's world. We find many mentions of interpreters in the Late Latin and Arabic medieval literature. The reason may be that in the Middle Ages the need for interpreters was more noticeable, due to the consolidation of new languages, the ensuing development of societies in different areas, the settlement of new regions and expeditions towards new and unknown territories.

The Arabs landed in Spain in 711, when Tarik conquered the Iberian Peninsula. He reached Poitiers, in present-day France, in 733, at which point his troops' expansion through Europe was halted by Charles Martel. At that point, Hispania became a centre of Muslim culture and civilization, remaining under Arab control until 1492, the year when the Catholic monarchs, Ferdinand and Isabella, oversaw the conquest of Granada. During these 800 years, culture flourished within the peninsula's borders and Spain became a world centre for arts and culture. Owing to the ongoing fighting, the borders between the Christian and Arab kingdoms fluctuated constantly during the 12th and 13th centuries. Many prisoners were 
captured, leading to the emergence of the "alfaqueques" - language brokers who were in charge of negotiating their return. This group of language brokers was first recognized in the 13th century by Alfonso the Wise (Baigorri, 2015; Foz, 1998).

The Middle Ages also witnessed a crucial chapter in the history of interpreting in war zones: The Crusades. The objective of these expeditions was to control Jerusalem ${ }^{12}$ and prevent it from falling into Saracen hands. The number of language-related problems that must have arisen during the Crusades was surely large. Troops were brought together from many regions to join these multinational expeditions at a time when many Western languages, including English, Gaelic, German, Slavonic, Italian, Spanish and French, were developing (Bischoff, 1961). Nearly 15 different nationalities or peoples were enrolled in these armies, from which we can infer that language brokers were a necessity. Despite the multilingual nature of the armies, however, the lingua franca was French, as the majority of foreign troops were Franks and Normans (Roland, 1999). Christians and Muslims continued their cultural and trade exchanges even while at war, which suggests that language-learning and interpreting were also necessary to facilitate such exchanges.

Although we assume that all sorts of interaction took place between the different parties, crusaders and Arabs alike, very few records of such interactions exist. Interpreters generally remain unidentified even in those records that do exist. One exception to this is the case of Ramón Llull, one of the most renowned missionaries of this period. He was a scientist and a prolific writer who spoke Arabic and preached to the Moors in Spain (Ausejo, 2004; Hillgarth, 1996). He is also known for his proposal to the Council of Vienna, the body in charge of overseeing the Knights Templar, regarding training missionaries to be sent to preach in Islamic lands (Roland, 1999).

\subsection{Europe and the New World}

In 1492, Christopher Columbus set off to locate the passage to India. $\mathrm{He}$ took with him a converted Jewish interpreter, Luis de Torres, who spoke Hebrew, Chaldean and Arabic fluently, in the belief that these languages would be useful in making contact with the local populations of the lands he hoped to reach. When the ships returned to Europe, Columbus brought six indigenous people back to learn Spanish and be useful to him in future expeditions.

It seems that the main method of communication between the indigenous population and Columbus, as well as later explorers, was sign language, though some members of the local population learned to communicate with Columbus and his crew very quickly (Umaña, 1991). Even preaching to the natives was often done entirely through signs. Missionary priests were true pioneers in linguistics, becoming the 
compilers of the first grammars and dictionaries of indigenous languages (De la Cuesta, 1992). Interestingly enough, some interpreters in this period were known by name, including Juan Ortíz, Jerónimo de Aguilar, Felipillo, Enrique de Malaca, and "La Malinche" or "Doña Marina", the most famous and researched of them all. She was a female slave given to Cortés who spoke Aztec and Mayan. She learned Spanish very quickly, and her command of these three languages made her indispensable to Cortés, not only as an interpreter, but also as an advisor.

The need for interpreters was also clear further north on the American continent. Interpreters can be found among the first Europeans to set foot in this part of the world. In French Canada the most notable interpreters were Mathieu da Acosta, the Jesuit Pierre Biard, Savignon, Etienne Brûlé and Nicolas Marsolet. Records from the colony of New France dating back to the beginning of the 17th century attest to a total of 12 interpreters. Most are registered in their first names, though there are others registered in their surnames. It appears that these were dedicated professionals whose sole professional activity was language mediation.

Samuel de Champlain, coloniser of New France and founder of Quebec City, was aware of the language demands arising in the new colonies and created an institution of resident interpreters to cater to them. The first "immersion" apprenticeship schemes were developed by sending French coureurs des bois to live with First Nations in order to learn the local language and way of thinking. Moreover, the interpreters trained in this fashion not only lived with the tribes; in order to fully integrate with the native people, they dressed like them and hunted, fished and interacted with them daily (Delisle \& Woodsworth, 2012).

Among the English settlers it seemed more difficult to find good interpreters. The most prominent are mentioned by name, including Conrad Weiser, George Croghan, Jacobus Clement and Daniel Claus from New York State. The most famous of all is Andrew Montour, who was employed by George Washington (Hagedorn, 1988; Kawashima, 1989).

The services of interpreters were clearly vital even after the American War of Independence. Mediators such as René Jaussame, Toussaint, Sacajawea, George Drouillard and Rousseau participated in the conquest of the Western part of the continent. This process was not always peaceful and required language brokering to establish links with the native peoples.

The first article included in this special volume deals with the role of the interpreter during this time frame. Verónica Murillo Gallegos, Anna Maria D'Amore and Krisztina Zimányi's "Have faith in your vocabulary. The role of the interpreter in the conquest of power, language and ideology in the New Spain" analyses the role interpreters and translators played in the indoctrination of the local populations against the backdrop of the conquest of New Spain. The authors carry out a thorough study of Los Coloquios (1524) - a text that aspired to reconstruct the Spanish Franciscan friars' first contact with and attempts to evangelize the 
indigenous population. When Columbus first set foot in the territories inhabited by the indigenous peoples of the Americas, he did not anticipate any of the communication challenges awaiting him. Quick solutions for tearing down the barriers blocking Spanish aims in the New World were critical, for communication had to be established. Aside from the typical logistical tasks, interpreters in this chapter of history were expected to perform a wide variety of duties. First and foremost, their main task was to evangelize and indoctrinate. They were used to spread Christianity, as bringing "the one true faith" to the natives was the excuse used by Spain to claim and annex these territories. Interpreters also acted as messengers or representatives of the Crown or of their superiors. They were also called upon to act as official witnesses when superiors were required to defend their actions before the Crown.

In their article, the authors focus on the first of the just-mentioned roles: involvement in the eradication of the customs and beliefs of the indigenous communities through military and political dominance as well as evangelization. Given the difficulty of finding or training interpreters suitable for the purposes of evangelization, proclaiming the Word of the Lord was a slow and painful process in those days. The authors analyse in depth the work Coloquios y doctrina cristiana con que los doce frailes de San Francisco enviados por el papa Adriano Sexto y por el emperador Carlos Quinto convirtieron a los indios de la Nueva España. En lengua mexicana y Española (1564). In this book, Fray Bernardino de Sahagún a missionary known to be one of the most accomplished European speakers of the "Mexican language"-compiled the talks between a group of Franciscan missionaries known as the Twelve and a group of Aztec chiefs which brought about the conversion to Christianity of the latter. The authors' meticulous and systematic analysis of this text helps us to understand the complex role of the interpreter in this conflict.

\subsection{From the Peace of Westphalia to 1914}

During the period that followed the European Peace of Westphalia (1648), nation-states and vernacular languages become more established. These developments led governments to realise the importance of having their own representatives at foreign courts (Mattingly, 1937). At the same time, French took the place of Latin as the lingua franca in diplomatic circles.

During this period a new trend arose: interpreters played a much more visible role. The position of interpreters in armed conflicts also became more evident, as can be observed in the records of Napoleon's campaign to Egypt and Palestine (1798-1801), in which we find references to translators and interpreters who spoke French and Arabic. Other references dating from the Napoleonic wars can also be found in records of the Russian campaign (Britten, 2000), where it is specifically mentioned that an interpreter was someone "to whom all the details of the affair could 
be confided and who would repeat what he was told in the proper quarters" (Caulaincourt, 2011, p. 125).

Around the same time, the position of dragoman emerged in the Ottoman court. These officials held a key role in the court, serving as language intermediaries between the Sultan and his bureaucracy (Lewis, 2005). The term comes from the Turkish "trucheman", and was anglicised to "dragoman" (plural: "dragomen"). Turkish dragomen wore a uniform, were paid relatively well and were even allowed to have assistants or student interpreters who, during their training, earned about one-quarter to one-half the salary of a fully-fledged dragoman. The practice of establishing permanent foreign legations and representatives in other countries began during this period and continues to the present day (Lee \& Hocking, 2011). Another crucial development during this period is that these professionals were trained for their duties. As early as 1806, Prince Adam Czartoryski urged the Russian Emperor Alexander I to found a school of international relations and foreign service in order to suitably train future foreign representatives and intermediaries.

In 1714 , the year after the Utrecht Treaty was signed, a new diplomatic practice was implemented; to wit, the "reservation" of the language to be used in the drafting of treaties. Although French maintained its status as lingua franca until the mid-20th century, English was becoming increasingly prominent during these years, due to the fact that from 1800 onwards foreign diplomats were received in English at St. James' Court. This practice was followed 60 years later by Lord Palmerston's statement that any government had the right to use their own language in foreign relations (Roland, 1999), which helped sow the seeds of change in the use of languages in the diplomatic world. Between 1814 and 1914, treaties were drafted in French, although the conflict between English and French resurfaced as early as the second Hague Convention, in 1907. After this date, speakers at international meetings used their own languages; such meetings therefore presumably required the participation of interpreters.

The second article included in this special volume belongs to this time period, but addresses a context and place very different from that described in the preceding paragraphs. Pin-ling Chang's "Wartime interpreting during the Sino-Dutch War (1661-1662)" focuses on interpreting practices during the Sino-Dutch War (1661-1662) in 17thcentury colonial Taiwan. It is one of the many articles included in this volume that explore the role of the interpreter in war times as a subcategory of "conflict". 13

The Sino-Dutch War was a protracted, multi-ethnic conflict between Europeans and Chinese, that required many written and oral interpretermediated negotiations. Most of these interactions were carefully documented in the archives of the Dutch East India Company (Vereenigde Oost-Indische Compagnie, VOC). Interpreters could, therefore, be seen as indispensable to this conflict. The article focuses on interpreters' 
backgrounds, functions, status, issues of loyalty and trust and on interpreting and translation as a tool for manipulation and power struggle. The article's focus on wartime interpreting data in pre-modern times is innovative considering the fact that very few studies deal with on-thebattleground interpreting practice in wartime. The author also compares the interpreters and the interpreting practices during the Sino-Dutch War with our present experience, thus bringing to light some differences between the past and the present.

\subsection{From 1914 to the Nuremberg trials}

After these two articles on interpreting in the 16th and 17th centuries, respectively, the focus of the special issue shifts to the 20th century and to World War I. During the Great War, interpreters facilitated communication between the Allies as well as between armies and civilians. The interpreters were typically military interpreters; that is, they were members of the military, enlisted or conscripted, who were called on to interpret during all types of war-related activities and at every stage of the conflict, including the lead-up to war and its aftermath. As far as we know, the majority of them were not professional interpreters before the war; they were selected for this duty on the basis of a good command of a particular foreign language.

Research on interpreting in this era of global conflict is scarce; our "portrait" of the interpreter during this era is not clearly delineated. Peter Cowley's "Declining the interpreter's role in World War I" is, therefore, an original and innovative study. $\mathrm{He}$ examines fictionalised and autobiographical accounts of the Great War by three French military interpreters: the writer Andre Maurois, the painter Paul Maze, and the cartoonist Hansi, who were officiers de liaison with the British Expeditionary Force. Although they worked as officiers de liaison during the Great War, there are interesting divergences in the evolution of their duties, and even more fascinating differences in their later accounts of them. Maurois' wartime experience of interpreting informs his novel Les Silences du Colonel Bramble and its sequels, while Hansi wrote a firsthand documentary account of his role in the creation of modern propaganda warfare, A travers les lignes ennemies. Comparing the experiences of these three wartime interpreters allows the author to explore the representation of military interpreters in this period, especially their regret at being excluded from the heroism of regular combat and the different ways they figure and work through that regret.

Despite the scarcity of academic enquiry into the role of the interpreter in World War I, the conflict and, in particular, the events that followed it, began to shape interpreting as we know it today. Many people emerged from this period as interpreters. The Paris peace negotiations following the war were a seminal moment for interpreting. Both English 
and French were adopted as the official languages of the conference. Many well-known interpreters appeared during this period, with Paul Mantoux and Gustave Henri Camerlynck being considered the most prominent. This was the golden age of the pioneers of conference interpreting, among whom we should mention Antoine Velleman, the founder of the School of Translation and Interpreting in Geneva (ETI); Jean Herbert, consecutive interpreter for the League of Nations and Chief Interpreter of the United Nations Interpretation Service in New York; and other well-known interpreters such as Robert Cofino, André Kaminker, Georges Kaminker and Rossetti Agresti, who were particularly brilliant harbingers of the profession (Baigorri, 2014a; Delisle and Woodsworth, 2012; Van Hoof, 1996).

The period between the two world wars is often considered the golden age of consecutive interpreting, as this was the manner in which speeches were rendered into a target language at the meetings of the newly established institutions such as the League of Nations. It was also during this period that the simultaneous mode of interpreting was conceived of and experimented with for the first time, albeit with limited acceptance. One could therefore argue that this progress in the field of conference interpreting arose from a conflict situation, i.e., the Great War.

The special issue continues with the second global war of the 20th century. As the events of World War II unfolded, it was once again abundantly clear that reliable interpreters were of the essence. As was the case during conflicts throughout history, those called upon to act as interpreters, especially for military and intelligence purposes, were usually not individuals who had previously self-identified as interpreters; rather, they were most often individuals who, through life experience, had gained a command of languages. Interpreters' allegiance was constantly called into question because of the often politically charged nature of their work. Interpreters were called upon in Japanese internment camps in the United States, occupied territories and concentration camps, as well as for meetings between key political players. Since what we would recognize today as formally trained interpreters were almost non-existent, it was often necessary to recruit individuals with language skills from the ranks of the perceived enemy.

Research on interpreting in World War II is more abundant than that relating to World War I. One particular dimension of interpreting that has attracted the attention of many scholars concerns the use of interpreters by the dictators and other prominent politicians involved in the 1939-1945 war. Other than Mussolini, the leading political figures of the time had almost no knowledge of foreign languages; consequently, interpreters were essential to them. The most famous examples are Hitler's primary interpreters, Paul Otto Schmidt and Eugen Dollmann. Other prominent interpreters of the time include Valentin M. Berezhkov, Stalin's interpreter; Arthur H. Birse, who interpreted for Churchill; and Charles E. Bohlen, who interpreted for Roosevelt and Truman. Many of the aforementioned 
interpreters wrote memoirs which provide a unique perspective on interpreting before and during World War II.

In the present volume, a total of four articles deal with World War II. María Gómez Amich's "The untold story: June's case study" is a thorough and noteworthy qualitative study that pays tribute to the people who worked with languages at the British Secret Intelligence Services (SIS), or MI6. The SIS was a branch of the British government that played an important role in supervising Bletchley Park's work on and eventual deciphering of German codes during World War II. She presents key extracts of a narrative interview carried out with a veteran MI6 linguist whose existence was kept highly guarded for more than 40 years. The interview is a unique first-hand account that provides insight into the role and the activities performed by an MI6 linguist. In this context, it is important to note that linguists are often a key link between raw intelligence and its end-users, and are responsible for developing a translation-evaluation-analysis of the information (Footitt \& Kelly, 2012). In addition to extracts of the interview, the author presents a thematic study of key details related to the decoding, translating and indexing activities performed by MI6 veterans. This comprehensive study helps us to understand the integral place of languages before and during World War II, and the role of MI6 linguists, including their position in intelligence translation, evaluation and analysis.

Pekka Kujamaki's "“And then the Germans came to town': The lived experiences of an interpreter in Finland during the Second World War" focuses on the Finnish-German military alliance in Northern Finland during World War II (1941-1944). This alliance created a dynamic and multilingual space where translation and interpreting were essential not only to military co-operation but also to the co-existence of Finnish civilians and the German military forces. Language mediation was carried out by military personnel (principally military interpreters and liaison officers) as well as by civilians (women, children) and prisoners of war with sufficient language skills.

To illustrate the translation and interpreting practices of this time and place, as well as the potential agency of civilian interpreters, this paper analyses two autobiographical manuscripts by Lahja Ikonen, who was recruited in 1942 as an interpreter for a German supply depot in Hyrynsalmi, Eastern Finland. During her service, she not only wrote down notes of her daily tasks, meetings, relations with soldiers and colleagues and confrontations between the Finnish and German parties, but also recorded her feelings about living in a male military space far away from home. The author's approach to this analysis is microhistorical, as indicated by the choice of material and focus on one person's perspective: the paper focuses on everyday translation and interpreting practice as experienced by a subaltern individual who has established complex relationships within the military and civilian social structures that surround her (Munday, 2014). Like other people who worked as interpreters in the 
20th century and wrote their personal memoirs, Ikonen's writings are the recollections of a person whose focus when writing was on the expression of her own personality rather than solely on her work as a wartime interpreter. The author highlights the importance of this fact to the analysis of wartime mediators' accounts - information included in these accounts is not only related to the interpreting work per se. The author's analysis of Ikonen's memoirs points to certain patterns in the translation culture in the historical-political context explored - patterns that, in our opinion, could be applied to other war-related contexts: the shortage of and need to recruit linguistic mediators, the fact that interpreters were usually identified by chance or circumstance, the widespread view that linguistic skills were the same as interpreting skills, and the endemic lack of training.

The focus remains on World War II in Malgorzata Tryuk's "Interpreting and translating in Nazi concentration camps during World War II". This paper examines the need for translators and interpreters in Nazi concentration camps as well as the duties and tasks required of these individuals. The author carries out a salient analysis of recollections and statements of former inmates collected in the archives of concentration camps. This collection of material is a unique example of the ontological narratives which relate the experiences of the victims of the Nazi regime (Kuhiwczak, 2007). She compares the ontological narratives with the cinematic character of Marta Weiss, a camp interpreter, as presented in the docudrama "Ostatni Etap" ("The Last Stage"), a film from 1948 by the Polish director Wanda Jakubowska, herself a former prisoner in a concentration camp. The author focuses on ethical issues, which are one of the essential problems raised by translation and interpreting scholars. The article aims to describe the activities of the Lagerdolmetscher, or camp interpreter, and to investigate why interpreters were needed, who they were, how they were recruited for the job, what their duties were, how they performed their duties and what their roles were. As the author herself mentions, this article contributes to the discussion about the role translators and interpreters play in extreme and violent situations, when the accepted ethical norms of translation and interpreting are no longer applicable. The recollections in Jakubowska's film illustrate the complex role of camp interpreters, including tasks which went far beyond the neutral transfer of information from one language to another. The interpreter found himself in an uneasy position because he had to perform his duties in the space between the oppressors and the oppressed.

After these three articles, we stay in the same period but move to a different geographical context. In his innovative article, "Augmenting combat power: Military translation in China-Burma-India Theater", Luo Tian examines military translation within the framework of military principles, proposing a framework to map out the role of military translation in war zones. He addresses the issue of military translation by referring to military theory and explores the case of interpreters in the China-Burma-India Theater ("CBI Theater") through the analysis of 
historical records and memoirs by the interpreters serving in the "CBI Theatre". "CBI Theater" is a term used by the United States Army for the battle zones of China, Burma, and India, where the Allied air and land forces fought against the Japanese army in the 1940s. The aim of this descriptive and interpretive case study is to understand the translation process in the "CBI Theater" and to test the applicability of the proposed framework to investigations of the role of translation in wartime. The author approaches the relevant data in the light of three aspects of combat power: tangible factors, intangible factors and the execution of combat power. The author uses specific examples of interpreters who worked in this theatre to illustrate interpreters' contributions to all three aspects. The author concludes that interpreters contributed greatly to the victory of the Alliance through bilingual service that increased tangible and other intangible factors of combat power. Interpreters helped transmit needed information and spread knowledge among different units of the Alliance; aided in the enhancement of tangible factors of combat power; boosted other intangible factors and contributed to the efficient execution of combat power. The author concludes that military translation can help reshape the combat power relations between the parties involved in conflicts, and ultimately influence the outcome of war.

We move away from World War II in the last article in this section. "Ethics, identity and ideology: A study of the interpreters in the war of resistance against Japanese Aggression (1937-1945)," by Ping Li, Chuanmao Tian and Zhonglian Huang, provides a detailed and systematic examination of various aspects of the interpreters in China's War of Resistance against Japanese Aggression (CWRJA), from 1937 to 1945. This article focuses on another war that was waged at the end of the first half of the 20th century. In this study, the authors revisit the concepts of interpreter ethics, identity and ideology as conceptualized over time. They analyse interpreters' professional ethics and situational ethics in armed conflict settings and discuss how professional ethics interacts with identity and ideology. The authors enumerate, define and analyse interpreters' professional ethics and individual morality in order to understand the role of the interpreter within society and within the professional environment. Their description of how codes of ethics are set by and for professionals takes into account Gouadec's (2007), Pym's (2001) and Inghilleri's (2012) views on the matter; the authors argue that a code of ethics should be understood as more than the common guidelines of a group of professionals who work in the same realm.

Once these basic concepts are defined and clarified, the relationship between individual morality and professional ethics is explored. Here, the authors argue that consideration of ethics as a macro category would lead us to identify a number of factors that influence it. This would seem a particularly relevant topic to study in this context, given the implication that individual morality would be influenced by war and, as a result, might change; it could therefore be argued that a state of war would necessarily 
change the role and status of the interpreter. The authors illustrate the dichotomy between individual morality and professional ethics, and discuss how the two might clash due to issues such as (1) the dual identity of the interpreter, (2) the unrealistic requirements of the interpreting industry, (3) the fact that not all interpreters are willing to comply with professional ethics, and (4) the interpreter's individual morality. The authors focus on the CWRJA and how identity and ideology unfolded on both sides, Japanese and Chinese. This analysis provides excellent insight into the difficulties that arise when interpreting in an armed conflict scenario. In analysing the impact of the factors described above on the neutrality of the interpreter, the authors describe various approaches to ethics as well as the complexity of war. Both these topics are timely, and allow us to understand better the dilemmas an interpreter might face during wartime.

\subsection{The Nuremberg trials}

The Nuremberg trials, another major event held in the aftermath of a war, shaped the future of interpreting considerably. The trials began on 20 November 1945. In total, a series of 13 trials was held between 1945 and 1949 in Nuremberg, Germany. The first trial was conducted in four languages: English, French, German and Russian, the languages of the Allied Powers and Germany (Biddle, 1947; Roland, 1999). This is what is known as the Nuremberg Trial proper or Main Trial. The other 12 trials, known as the Subsequent Proceedings, took place in German and English, as the tribunals for these trials were formed solely by American judges (Gaiba, 1998). The Nuremberg Trials were the result of a decision to prosecute Axis leaders taken in Yalta by Roosevelt, Churchill and Stalin. As early as 1943, the Allies had warned the Axis powers that any perpetrators would be made accountable for their crimes before a court of law. The Nuremberg Trials are considered the birthplace of modern conference interpreting.

The first time an official declaration was made with regard to the eventual prosecution of those responsible for perpetrating violence against European Jews and the civilian population in general was December 1942. The options for punishment of the perpetrators included a proposal to execute 50,000 to 100,000 German Staff Officers and the possible summary execution of the defendants. In the end, however, the American leaders' proposal of holding a criminal trial and treating the case as a German criminal plot prevailed, for a variety of reasons. The most important of these was that documentation and proof of the accusations during the course of the trial would avoid potential claims that the defendants had been judged and sentenced without evidence; this process also ensured the defendants' right to a fair trial. 
Given the multilingual nature of the proceedings, language management issues were of central importance from the outset. The linguistic diversity of those involved in the trial meant that interpreting would be required. Both whispered and consecutive interpreting had been used in multilingual forums in the past, but neither of these modes was considered ideal for use at Nuremberg - consecutive because it would unreasonably prolong the sessions, and whispering because of the fact that the interpreter's voice would interfere with that of the speaker. Consecutive interpreting also required individuals who had already listened to the interpretation into their language to wait and listen to renditions in languages they did not understand. Consequently, the decision to use simultaneous interpreting was made (Baigorri, 2014a; Delisle \& Woodsworth, 2012; Gaiba, 1998; Roland, 1999).

Texts discussing the Nuremberg Trials (Gaiba, 1998) name Léon Dostert as the promoter of simultaneous interpreting at Nuremberg. Convinced that if simultaneous interpreting were not used the trial would never end, he embarked on a mission to persuade the parties involved to use the new system. The decision to use simultaneous interpreting was finally made in October 1945 (Biddle, 1947; Gaiba, 1998). IBM provided the equipment free of charge and the necessary technical staff were trained to operate the equipment during the trials (Bowen \& Bowen, 1985; Gaiba, 1998).

Apart from linguistic diversity and its associated difficulties, the trial involved legal and procedural complications. One example of these hurdles is that the trial was an international one, thus bringing the laws of different nations, with their varied legal traditions and practices, into contact. Another complication was the fact that the tribunal's procedures had not yet been fully established. To resolve this issue, the rules of procedure enshrined in the London Charter of the International Military Tribunal (issued on 8 August 1945) were adopted. They included provisions such as requiring defendants to submit requests with enough time in advance for presentation of witnesses and documents related to their cases; drafting a clear definition and categorisation of crimes by combining Anglo-American and Continental law, in order to have a straightforward definition and distinction between crimes against peace, war crimes and crimes against humanity for the purposes of the trials and ensuring that both civilian staff and military officers could be charged with war crimes ("Nuremberg Trials", n.d.).

\subsection{From Nuremberg to the 21 st century}

The volume concludes with a section devoted to the second half of the 20th century and the beginning of the 21 st century. Binhua Wang and Minhui $\mathbf{X u}$ present a comprehensive and original study entitled "Interpreting conflicts, conflicts in interpreting - A micro-historical account of the 
interpreting activity in the Korean Armistice Negotiations", in which they examine one of the major historical events that shaped the geopolitical situation in East Asia after World War II. In contrast to other studies on the Korean Armistice Negotiations that have dealt with

the international and national settings, the leading delegation members and the major issues of the negotiations, such as the ceasefire arrangement, the demilitarized zone and the repatriation of prisoners of war, and on the aftermath of the war (p. 187),

this paper focuses on the "omnipresent facilitators" of the trilingual negotiations - the interpreters themselves. The purpose of the article is to contextualize (1) interpreting activity in wartime negotiations, (2) the complexity of the role of the interpreters and (3) the interpreters' perception of various conflicts involved in the negotiations. A microhistorical approach is used: the authors analyse "post hoc accounts" (p. 187) of the interpreters and parties involved in the historical event. The article explores the complexities of the interpreting activity (preparation, setting of the negotiations, tensions between the working languages), conflicts perceived by the interpreters, and the norms and ethics for the interpreting activity. The study paints a picture of the complex role of interpreters working during wartime negotiations and reveals some conflicts involved in interpreting the armistice negotiations as perceived by the interpreters, as well as intense conflicts related to interpreting. Conflicts existed or arose between the interpreters on the two sides of the negotiations, between the interpreters and their principals, between the different roles of the interpreters, over language usage between the two sides of the negotiations and from misconceptions regarding interpreting.

Moving forward in time, we come to Svetlana Probirskaja's "How do interpreters become heroes? Narratives on Soviet/Russian military interpreters". In this article, the author delves into the narratives and stories about Soviet/Russian wartime/military interpreters by examining popular science articles, websites, online media articles, the autobiographical writings of interpreters and documentaries. This analysis aims to identify recurring features that could lead us to see personal narratives embedded in public ones, as suggested by Baker (2006). To this end, the author carefully scrutinises the Great Patriotic War (1941-1945), the war in Afghanistan (1979-1989) and the MIFL's (Military Institute of Foreign Languages) role in training interpreters to work in war scenarios, providing a timeline of events in the 20th century. This in-depth perspective allows the reader to understand (1) how a particular war is perceived by society; (2) the impact that these perceptions have on attitudes towards the veterans of a particular war, and (3) that, despite the MIFL's prominent role, academic research on Soviet/Russian military interpreting and translation is nearly non-existent, reminding us once again of the frequent invisibility of the interpreter in the historical and academic records. 
The author draws on a number of narratives in order to recount and examine the role of Soviet/Russian interpreters. She first describes the meta-narrative of the Great Patriotic War and examines the role of interpreters during the war, noting that its veterans were later viewed positively by society. She contrasts the narrative surrounding the Great Patriotic War with that surrounding the war in Afghanistan. The latter war became, in the author's words "lost", "forgotten", or "hidden" (p. 212-213) and, as a result, its veteran interpreters were much less visible than their predecessors had been.

The final narrative examined in the paper is that of the MIFL, in which we learn of the origins of Soviet military interpreting and translation. This account describes the official creation of the post of the military interpreter in 1929 and the provision of a defined status to this professional figure. It also describes one of the first programmes dedicated to training war interpreters. We also hear from alumni of the MIFL, who share their personal views and highlight the importance of military interpreting and translation.

The paper also explores the "scouts' brothers" narrative, according to which interpreters were closely related to military intelligence, taken on reconnaissance missions and played a highly appreciated role. Related to the "scouts" brothers" narrative is the "invisible soldiers" narrative, according to which interpreters carry out tasks and roles unknown to the public and are therefore invisible. Overall, the article provides the reader with a comprehensive overview of a previously underexplored chapter of interpreting history - the role and participation of war interpreters during the Soviet era.

In "Interpreting conflict mediation in Kosovo and Macedonia", Marija Todorova describes increasing scholarly interest in the role of interpreters in processing military data; facilitating communication between armies, the local population, and the media and studying war prisoners (Apter, 2010; Baker, 2010; Dragovic-Drouet, 2007; Inghilleri, 2005; Palmer, 2007; Rafael, 2007; Stahuljak, 2000). It argues that existing accounts do not place sufficient emphasis on the critical role of interpreters in conflict resolution, peace negotiations, mediation and other similar situations. The importance of interpreters during mediation is highlighted by two sets of data: first, a survey of approximately 100 interpreters involved in Track 2 mediation during the violent conflicts in Macedonia and Kosovo, and, second, by in-depth interviews with two interpreters and two mediators involved in Track 1 mediation activities. Both studies demonstrate that the interpreter's role in conflict mediation is an active one, resembling that of mediators or quasi-mediators (Kriesberg, 1991). Interpreters therefore need specific skills, knowledge and experience in order to fulfil this role successfully.

The conflicts in Kosovo and Macedonia are very closely connected. During the Kosovo conflict, Albanian and Roma refugees leaving Kosovo took temporary refuge in Macedonia. The Kosovo crisis of 1999/2000 
ended with UN Security Council Resolution 1244, a result of the peace negotiations between Serbian and Kosovar Albanian representatives, facilitated by Martti Ahtisaari, representing the international community. In 2001 in Macedonia, EU representative Francois Leotard and US representative James Perdue, together with official and unofficial leaders of the country, signed the Ohrid Framework Agreement, putting an end to the violent conflict between the Macedonian and Albanian communities. In both conflict situations, the two antagonistic communities spoke different languages (Albanian/Macedonian and Albanian/Serbian, respectively). In both cases, the third party brought in the English language as the language of mediation.

This paper looks at the issue of neutrality, defining it and revisiting it through the lens of conflict mediation theory (Bercovitch, 1996; Gulliver, 1979; Touval, 2002) as well as through interpreting theory. Touval (2002), arguably one of the harshest critics of mediators' neutrality, has made a powerful argument that biased mediators are often the most effective in international disputes. Kriesberg (1991) introduces the term quasimediator, that is, a person who may belong to one of the parties in conflict, but is not officially appointed as a mediator. The idea of the translator as mediator is not new in translation studies. In this study, however, interpreters' mediating function is analysed within the context of conflict mediation. Although the fundamental role of interpreters is to facilitate communication, the role of interpreters in conflict mediation and thirdparty intervention often goes beyond the usual role and skills needed by interpreters in other situations. Interpreters in conflict mediation need to be more sensitive to the background situation and to emotions, and they need to be able to sense perceptions and feelings. They also need to help the mediator create trust and open communication and understand cultural differences and emotions.

Mihaela Tălpas' "Words cut two ways. An overview of the situation of Afghan interpreters at the beginning of the 21 st century" explores the role of interpreters working with international coalition forces during and after the war in Afghanistan (2001-2015). The author notes that Europe's international relations at the end of the 20th century and the beginning of the 21 st century were based on dialogue and co-operation across borders. After the terrorist attacks of 11 September 2001, conflicts broke out in various regions, particularly in the Middle East. Interpreting practice in these conflicts was influenced by a number of environmental factors, including the languages involved and the situation in those countries as a result of post-colonialism. In this context, as we have seen in the other conflicts discussed in this foreword, Afghan interpreters performed several roles, not only that of interpreters. The author analyses a corpus of online interviews and articles, specialised journals, reports and literature containing the opinions and experiences of interpreters in Afghanistan and of the parties they interacted with. She explores the challenges Afghan interpreters faced in terms of dangers or risks in the 
field. She pays particular attention to the risks normally associated with being a soldier, analysing the extent to which they also affected Afghan interpreters. The evidence she presents justifies a dual-role conceptualization of interpreter as soldier. The author identifies risks arising from the context in which the interpreters worked and categorizes them as military, natural and social in nature. The risks faced by the interpreters are very similar to those faced by military personnel, which include risks related to geopolitical context, geographical location, social constraints, linguistic needs, language resources, technical shortcomings and logistic and administrative elements. The article also examines the usefulness of taking factors such as culture and religion into account when interpreting.

Pekka Snellman's article "Constraints and dimensions of military interpreter neutrality" describes military interpreters as soldiers who are proficient in foreign languages and cultures and are assigned to interpretation duties. This means that military interpreters have military training, typically wear a uniform and insignia and carry weapons. It is interesting to note that of all interpreters working in present-day military operations, military interpreters constitute a minority. This fact is reflected in research: although a number of studies explore interpreting and the military, only a few have focused on military interpreters.

By definition, military interpreters' duties involve facilitating the objectives of military operations. This means that military interpreters cannot be viewed as neutral mediators in the sense traditionally attributed to interpreters (Lewis, 2012). The conceptualization of interpreters as neutral is problematic when applied to military interpreters (Kelly \& Baker 2013, p. 156). Indeed, military interpreters view themselves primarily as soldiers rather than interpreters (Kelly \& Baker, 2013; Snellman, 2014).

This article contributes to the discussion on interpreters' loyalty by addressing and delimiting this concept as it applies to military interpreters. To this end, the author draws on data obtained from interviews with 14 Finnish military interpreters who have served in crisis management operations as well as on the author's own experiences serving in Afghanistan. The result is a unique perspective on military interpreters' agency in the crisis management force, encompassing topics such as recruitment, experiences and motivation. The interview data suggests that the notion of neutrality is more complicated for military interpreters than for their civilian counterparts. Another conclusion is that military interpreters may not always be considered neutral, which leads to questions related to the dimension in which military interpreters' neutrality is defined, the terms in which their neutrality is constrained and the adequacy of civilian interpreters' professional ethical guidelines for military interpreters.

The concept of military interpreters' neutrality is framed by the concept of trust: to be able to perform their duties, they must be trusted (cf. Snellman, 2014, pp. 96-97). Trust is a significant aspect of interpreting in 
civilian environments too, and the interpreter's neutrality is the cornerstone on which this trust is built. Trust becomes a matter of perspective, as it derives from interpreting service users' perceptions of interpreters' neutrality. For military interpreters working in crisis management operations, trust is no less important, but it comprises multiple dimensions. At the physical level, military interpreters act within a military structure and have thus unquestionably chosen their allegiance. Wearing a military uniform and carrying a weapon conveys a message of ultimate trust (Jones $\&$ Askew 2014, p. 179). At a linguistic level, trust is a matter of interpreter competence. At a cultural level, the military interpreters' military training may be crucial, as trust in military organizations characteristically has its foundations in merits other than neutrality, such as military culture, nationality and esprit de corps.

In the last article of this volume, "Translation, hospitality and conflict: Language mediators as an activist community of practice across the Mediterranean", Annarita Taronna describes the impact that the massive increase in migration flows through the Afro-Mediterranean routes has had during the past few decades. This migration has reshaped previously homogeneous populations into linguistically and culturally diverse ethnoscapes. This new situation requires the definition of new translation scapes in which the practice of language mediation by translators and interpreters is performed as an act of negotiation, resistance, activism and hospitality towards the newly arrived migrants who have escaped from conflict zones and landed in southern Italy. The paper draws on 12 interviews with volunteer interpreters, translators and cultural mediators in order to examine the communicative and translation processes involved in their interaction with recent migrant arrivals in southern Italy. The author addresses three main research issues. First is the use of English as a lingua franca in language and cultural mediation, with a particular focus on how this language may be perceived either as a barrier or as a bridge. This strand of the investigation sheds light on how language can affect the relationship between the mediator and the migrant and the way in which the politics of hospitality is shaped in the Mediterranean. Second, the paper explores the linguistic and extra-linguistic strategies that volunteers, translators and cultural mediators have adopted not only for communicative purposes, but also to humanize the migrants' transfer to and internment in refugee camps across Italy. Finally, the author looks at the interviewees' narratives as a testimony of negotiation, activism and resistance to the strictly institutionalized protocols of the Italian immigration policies. The research findings suggest that the language mediators interviewed for this study are more than a group of individuals engaged in linguistic transfer; they have established a community that is a "living network" (p. 298) held together by a conscious and critical understanding of the performative power of their words. 


\section{Conclusion}

This issue of Linguistica Antverpiensia is a testimony to the fact that interpreting in conflict zones is crucial and complex. The general historical overview demonstrates that interpreters and language mediators have been present during wartime throughout history. At the same time, we have seen that the presence of interpreters in the past is largely undocumented in written historical texts, with the exception of some difficult-to-find, though valuable, sources, including historical texts and records, archival documents, autobiographical accounts, personal memoirs and recollections, interviews, narratives and documentaries. This situation makes it difficult to understand the development of interpreting as a profession in general and even more so in war zones. We have also noted that interpreters have been used in war-related scenarios, including negotiations and encounters or conversations of a political and conflictive nature. Although interpreters often go unnoticed, it seems clear that they have played an important role in events and episodes throughout history. Moreover, some of the most significant events in the development of the modern conceptualization of the interpreting profession, such as the Paris Peace Conference and the Nuremberg Trials, took place after a period of conflict in which interpreters played an important role.

One of the most interesting findings of this volume is that, despite the position the interpreter has played in conflict scenarios, no provision has been made for training interpreters specifically to work in those settings, with few exceptions. Owing to this situation, those working as interpreters in conflict zones have rarely received training in interpreting. One could argue that this still holds true today, as war interpreter training programmes are still rare. A similar point can be made with regard to the interpreters' status: although the status of interpreters working in war scenarios has been higher than that of other interpreters in some countries and at some moments in time, this has tended to be an exception to the general rule. Overall, the status of interpreters has been low throughout history, and interpreting in conflict zones has not become professionalized. In fact, unlike other settings that experienced such an evolution, including interpreting for international conferences, the working requirements, conditions and description of interpreting during war are not yet well defined.

A lack of definition and clear roles has characterized the interpreter's working environment throughout history, a fact which leads us to believe that specific elements should be more clearly defined in training programmes for war settings. These elements include the role and position of the interpreter in the communication process, the interpreting tasks to be performed, the skills needed to perform the job successfully, the type and extent of conflict-related training to be provided to interpreters, the type and extent of conflict-related duties that would be expected of the interpreter and, last but not least, issues related to ethics and neutrality. 
Another little-explored issue is the categorisation of interpreters in conflict. We believe that more research is needed in order to analyse the various types of interpreter who work in conflict zones and situations. A crucial first step in this process would be to consider the type and nature of the conflict, its background, the type of meeting or event, as well as the specific stage of the conflict.

In conclusion, we believe that this historical review is useful because learning from the past allows us to understand better the present. It allows individuals to engage more critically and effectively with current situations and needs and to find better ways to respond to them. Knowledge of history can help us identify different ways to approach present-day situations more critically and to offer objective insights into subjective matters that affect all the parties - whether interpreters, military staff or armed forces - present in the theatre of conflict.

\section{References}

Allen, K. (2012). Interpreting in conflict zones. Retrieved from http://najit.org/blog/?p=229.

Andres, D. (2012). History of interpreting. In C. A. Chapelle (Ed.), The encyclopaedia of applied linguistics. Oxford: Blackwell.

Apter, E. (2010). Philosophical translation and untranslatability: Translation as critical pedagogy. Profession, 14, 50-63. doi:10.1632/prof.2010.2010.1.50.

Ausejo, E. (2004). La cuestión de la obra científico-matemática de Ramón Llull. In Actas del VIII Congreso de la Sociedad Española de Historia de las Ciencias y de las Técnicas (pp. 21-34). Logroño: Servicio de publicaciones de la Universidad de La Rioja.

Baigorri Jalón, J. (2011). Wars, languages and the role(s) of interpreters. In H. Awaiss \& J. Hardane (Eds.), Les liaisons dangereuses: Langues, traduction, interprétation (pp. 173-204). Beirut: Sources-Cibles.

Baigorri Jalón, J. (2014a). From Paris to Nuremberg: The birth of conference interpreting. Amsterdam: John Benjamins.

Baigorri Jalón, J. (2014b). Two centuries of diplomatic interpreting: From top hat to short sleeves diplomacy. United Nations Chronicle, 51(3), 44-47. doi:10.18356/b4a26fd6-en.

Baigorri Jalón, J. (2015). The history of the interpreting profession. In H. Mikkelson \& R. Jourdenais (Eds.), The Routledge handbook of interpreting (pp. 11-28). London: Routledge.

Baker, C. (2010a). It's not their job to soldier: Distinguishing civilian and military in soldiers' and interpreters' accounts of peacekeeping in 1990s BosniaHerzegovina. Journal of War and Culture Studies, 3, 137-150. doi:10.1386/jwcs.3.1.137_1.

Baker, C. (2010b). The care and feeding of linguists: The working environment of interpreters, translators, and linguists during peacekeeping in Bosnia- 
Herzegovina. War \& Society, 29(2), 154-175. doi:10.1179/204243410X12674422128993.

Baker, M. (2006). Translation and conflict. London: Routledge.

Baker, M. (2010). Interpreters and translators in the war zone. Narrated and narrators. The Translator, 16(2), 197-222. http://dx.doi.org/10.1080/ 13556509.2010.10799469.

Bellos, D. (2011). Is that a fish in your ear?: Translation and the meaning of everything. New York: Faber and Faber.

Bercovich, J. (Ed.). (1996). Resolving international conflicts: The theory and practice of mediation. Boulder: Lynne Reinner.

Biddle, F. (1947). The Nuremberg Trial. American Philosophical Society Proceedings, 91(3), 294.

Bischoff, B. (1961). The study of foreign languages in the Middle Ages. Speculum, 36, 209-224. http://dx.doi.org/10.2307/2847789.

Blumenthal, H., \& Kahane, R. (1979). Decline and survival of western prestige languages. Language, 55(1), 183-198.

Bos, G., \& Soeters, J. (2006). Interpreters at work: Experiences from Dutch and Belgian peace operations. International Peacekeeping, 13(2), 261-268. doi:10.1080/13533310500437662.

Bowen, D., \& Bowen, M. (1990). Editors remarks. In D. Bowen \& M. Bowen (Eds.), Interpreting-Yesterday, today, and tomorrow. (p. 1). Amsterdam: John Benjamins.

Brahm, E. (2003). Conflict stages: Website beyond intractability. Retrieved from http://www.beyondintractability.org/essay/conflict-stages.

Brand, C. M. (1968). Byzantium confronts the West 1180-1204. Cambridge, MA: Harvard University Press.

Britten. P. A. (2000). 1812-Napoleon's invasion of Russia. London: Greenhill Books.

Cáceres Würsig, I. (2012). The jeunes de langues in the eighteenth century: Spain's first diplomatic interpreters on the European model. Interpreting, 14, 127-144. doi:10.1075/intp.14.2.01 cac.

Campbell, B. (2001). Diplomacy in the Roman world (c. 500 BC-AD 235). Diplomacy \& Statecraft, 12(1), 1-22. doi:10.1080/09592290108406185.

Caulaincourt, A.L. (2011). Memoirs of General Caulaincourt. The Russian campaign. Sevenoaks: Pickle Partners.

Child, J. (2010). Introduction to Spanish translation. Lanham, MD: University Press of America.

Chrobak, M. (2013). For a tin ingot: The archaeology of oral interpretation. Przektadaniec, Special Issue, 87-101. doi:10.4467/16891864ePC.13.039.1456.

Clausewitz, C. von. (1832/1918). On war (Vol I). Retrieved from http://www.gutenberg.org/files/1946/1946-h/1946-h.htm.

Collier, C.A. (2010, September-October). Now that we're leaving Iraq, what did we learn? Military Review, 90(5), 88-93.

De la Cuesta, L.A. (1992). Intérpretes y traductores en el descubrimiento y conquista del nuevo mundo. Livius, 1, 25-34. Retrieved from http://www.histal.ca/es.

Delisle, J., \& Woodsworth, J. (2012). Translators through history. Amsterdam: John Benjamins. 
Diener, B. (1938). Imperial Byzantium. Boston, MA: Little Brown.

Dragovic-Drouet, M. (2007). The practice of translation and interpreting during the conflicts in the former Yugoslavia (1991-1999). In M. Salama-Carr (Ed.), Translating and interpreting conflict (pp. 29-40). Amsterdam: Rodopi.

Footitt, H., \& Kelly, M. (Eds.). (2012). Languages at war. Basingstoke: Palgrave Macmillan.

Foz, C. (1998). Le traducteur, l'Eglise et le Roi: Espagne, XIIe et XIIIe siècle. Ottawa, ON: University of Ottawa Press.

Gaiba, F. (1998). History of interpreting: Interpretation at the Nuremberg Trial. Ottawa, ON: University of Ottawa Press.

Galán Allué, J.M. (1995). Aspectos de la diplomacia del Antiguo Egipto. Hasta CA. 1320 A.C. Sefarad: Revista de Estudios Hebraicos, Sefardies y de Oriente Próximo, 55, 105-126. Retrieved from http://digital.csic.es/bitstream/10261/19177/1/2009 1119101339972.pdf.

Galán Allué, J.M. (2011). Intérpretes y traducciones en el Egipto imperial. Sémata: Ciencias Sociais e Humanidades, 23, 295-313. doi:10.15304/s.23.175.

Gehman, H.S. (1914). The interpreters of foreign languages among the Ancients: Study based on Greek and Latin sources (Doctoral dissertation, University of Pennsylvania). Retrieved from https://ia601403.us.archive.org/13/items/interpretersfor01gehmgoog/interprete rsfor01gehmgoog.pdf.

Gouadec, D. (2007). Translation as a profession. Amsterdam: John Benjamins.

Gulliver, P. H. (1979). Disputes and negotiations: A cross-cultural perspective. New York, NY Academic Press III.

Hagedorn, N. L. (1988). A friend to go between them: The interpreter as cultural broker during Anglo-Iroquois Councils, 1740-70. Ethnohistory, 35(1), 60-80. doi: $10.2307 / 482433$.

Hermann, A. (1956/2002). Interpreting in Antiquity. In F. Pöchhacker \& M. Shlesinger (Eds.), The interpreting studies reader (pp. 15-22). London: Routledge.

Hillgarth, J. N. (1996). Vida i importância de Ramon Llull en el context del segle XIII. Anuario de Estudios Medievales, 26, 967-978. doi:10.3989/aem.1996.v26.i2.

Hodgman, A. W. (1915). A rejoinder. The Classical Weekly, 9, 8. doi:10.2307/4387127.

Hultsch, F. O. (1889/2012). The histories of Polybius. Translated by Evelyn S. Shuckburgh. Retrieved from http://www.gutenberg.org/files/44125.

Hutton, J., \& Marzouk, S. (2012). The morphology of the tG- Stem in Hebrew and Tirgalt̂̂ in Hos 11:3. Journal of Hebrew Scriptures, 12, 1-41. doi:10.5508/jhs.2012.v12.a9.

Inghilleri, M. (2005). Mediating zones of uncertainty: Interpreter agency, the interpreting habitus and political asylum adjudication. The Translator, 11(1), 69-85. doi:10.1080/13556509.2005.10799190.

Inghilleri, M. (2008). The ethical task of the translator in the geo-political arena: From Iraq to Guantanamo Bay. Translation Studies, 1(2), 212-223. doi:10.1080/14781700802113556.

Inghilleri, M. (2009). Translators in war zones: Ethics under fire in Iraq. In E. Bielsa \& C. Hughes (Eds.), Globalisation, political violence and translation (pp. 207221). Basingstoke: Palgrave Macmillan. 
Inghilleri, M. (2010). You don't make war without knowing why: The decision to interpret in Iraq. The Translator, 16(2), 175-196. doi:10.1080/13556509.2010.10799468.

Inghilleri, M. (2012). Interpreting justice: Ethics, politics and language. New York, NY: Routledge.

Ingold, C. (2014). Cross-cultural competence plus language: Capturing the essence of intercultural communication. In R. Greene Sans \& A. Greene-Sans (Eds.), Cross-cultural competence for a twenty-first-century military: Culture, the flipside of COIN (pp. 303-315). Lanham, MA: Lexington Books.

Jones, I., \& Askew, L. (2014). Meeting the language challenges of NATO Operations: Policy, practice and professionalization. Basingstoke: Palgrave Macmillan.

Juvinall, B. (2013). Heaven or Hell?: The plight of former wartime interpreters of the Iraq and Afghanistan conflicts living in the U.S. Michigan State Journal of International Law, 21, 205-227. Retrieved from http://digitalcommons.law.msu.edu /cgi/viewcontent.cgi?article=1110\&context=ilr.

Kawashima, Y. (1989). Forest diplomats: The role of interpreters in Indian-White relations on the early American frontier. American Indian Quarterly, 13, 1-14. doi: $10.2307 / 1184083$.

Kelly, M., \& Baker, C. (2013). Interpreting the peace: Peace operations, conflict and language in Bosnia-Herzegovina. Basingstoke: Palgrave Macmillan.

Kriesberg, L. (1991). Formal and quasi-mediators in international disputes: An exploratory analysis. Journal of Peace Research, 28(1), 19-27. doi:10.1177/0022343391028001004.

Kuhiwczak, P. (2007). The grammar of survival. How do we read Holocaust testimonies. In M. Salama-Carr, (Ed.), Translating and interpreting conflict (pp. 61-74). Amsterdam: Rodopi.

Kurz, I. (1985). The rock tombs of the princes of Elephantine: Earliest references to interpretation in Pharaonic Egypt. Babel, 31, 213-218. doi: $10.1075 /$ babel.31.4.05kur.

Lee, D., \& Hocking, B. (2011). Diplomacy. In B. Bardie, D. B. Schlosser, \& L. Morlino (Eds.), International encyclopaedia of political science. Los Angeles, CA: Sage.

Lewis, B. (2005). From Babel to dragomans: Interpreting the Middle East. New York, NY: Oxford University Press.

Lewis, J. (2012). Languages at war: A UK Ministry of Defence perspective. In H. Footitt \& M. Kelly (Eds.), Languages and the military: Alliances, occupations and the peace building (pp. 175-185). Basingstoke: Palgrave Macmillan.

Mairs, R. (2011). Translator, traditor: The interpreter as traitor in classical tradition. Greece \& Rome, 58, 64-81. doi:10.1017/S0017383510000537.

Mattingly, G. (1937). The first resident embassies: Mediaeval Italian origins of modern diplomacy. Speculum, 12, 423-439. doi:10.2307/2849298.

Moser-Mercer, B., \& Bali, G. (2008). Interpreting in zones of crisis and war: AIIC. Retrieved from http://aiic.net/page/2979/interpreting-in-zones-of-crisis-andwar/lang/1. 
Munday, J. (2014). Using primary sources to produce a microhistory of translation and translators: theoretical and methodological concerns. The Translator, 20(1), 64-80. doi:10.1080/13556509.2014.899094.

Ozawa, T. (2008). Nisei interpreters/translators of the US military. JICA: Journal of the Japanese Overseas Migration Museum, 3, 37-50. Retrieved from http://www.jomm.jp/kiyo/pdf/pdf3/kiyou200903.pdf.

Palmer, J. (2007). Interpreting and translation for Western media in Iraq. In M. SalamaCarr (Ed.), Translating and interpreting conflict (pp. 13-28). Amsterdam: Rodopi.

Peretz, D. (2006). The Roman interpreter and his diplomatic and military roles. Historia: Zeitschrift für Alte Geschichte, 55, 451-470.

Pöchhacker, F. (2004). Introducing interpreting studies. London: Routledge.

Pym, A. (2001). (Ed.). (2001). Introduction: The return to ethics in translation studies. Special issue of The Translator, 7(2), 129-138. doi:10.1080/13556509.2001.10799096

Rafael, V. (2007). Translation in wartime. Public Culture, 19(2), 239-246. doi:10.1215/08992363-2006-034.

Ringler, S. (1999). Sous le regard d'Hermes. Hermēneus, 1, 1-15. Retrieved from http://recyt.fecyt.es/index.php/HS/ article/view/6018/5727.

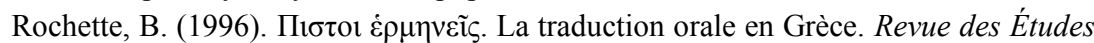
Grecques, 109(2), 325-347. doi:10.3406/reg.1996.2688.

Roland, R. A. (1999). Interpreters as diplomats: A diplomatic history of the role of interpreters in world politics. Ottawa, ON: University of Ottawa Press.

Sheehan, M. (2008). The changing character of war. In J. Baylis, S. Smith, \& P. Owens (Eds.), The globalization of world politics: An introduction to international relations (pp. 216-227). Oxford: Oxford University Press.

Snellman, P. (2014). The agency of military interpreters in Finnish crisis management operations (Master's thesis, University of Tampere). Retrieved from http://urn.fi/URN:NBN:fi:uta-201403061187.

Stahuljak, Z. (2000). Violent distortions: Bearing witness to the task of wartime translators. TTR, 13(1), 37-51. doi:10.7202/037392ar.

Stahuljak, Z. (2009). War, translation, transnationalism: Interpreters in and of the war (Croatia, 1991-1992). Translation Studies, III, 345-374.

Tadmor, H. (1991). On the role of Aramaic in the Assyrian Empire. In M. Mori, H. Ogawa, \& M. Yohikawa (Eds.), Near Eastern Studies 5 (pp. 419-426). Leiden: Brill.

Takeda, K. (2009). Wars and interpreters. Across Languages and Cultures, 10(1), 4962.

Takeda, K., \& Baigorri Jalón, J. (2016). New insights in the history of interpreting. Amsterdam: John Benjamins.

Tănase, T., \& Muscalu, B. (2013). Viewpoints on Roman traditions in the history of intelligence services. In G. Preda \& R. Ciuceanu (Eds.), History and civilization: EU strategy for the Baltic region (EUSBR) (pp. 7-29). Palermo: Italian Academic Publishing. 
Taulbee, J.L. (1998). Mercenaries and citizens: A comparison of the armies of Carthage and Rome. Small Wars \& Insurgencies, 9(3), 1-16. doi:10.1080/09592319808423218.

Taylor, T. (1955). The Nuremberg trials. Columbia Law Review, 55, 488-525. doi:10.2307/1119814.

Torregaray Pagola, E. (2009). Legatorum facta: La ejemplaridad de los embajadores romanos. Veleia, 26, 127-152. Retrieved from http://www.a360grados.net /sumario.asp?id=2465.

Touval, S. (2002). Mediation in the Yugoslav wars: The critical years. London: Palgrave Macmillan.

Umaña Chaverri, J. O. (1991). Interpretación y traducción de América en el diario de navegación de Cristobal Colón. Letras, 1(25-26), 107-120. Retrieved from http://www.revistas.una.ac.cr/index.php/letras/article/view/4041/3879.

Van Hoof, H. (1996). De l'identité des interprètes au cours des siècles. Hieronymus Complutensis, 3, 9-19. Retrieved from http://cvc.cervantes.es/lengua/ hieronymus /pdf/03/03_009.pdf.

Vieira, A. (2014). Complications in cross-cultural communications: Using interpreters. In R. Green-Sans \& A. Greene-Sans (Eds.), Cross-cultural competence for a twenty-first-century military: Culture, the flipside of COIN (pp. 195-210). Lanham, MD: Lexington Books.

Walbank, F.W. (n.d.). Polybius. In Encyclopaedia Britannica. Retrieved from https://www.britannica.com/biography/Polybius.

1 Early Dynastic List E. It probably dates back to the protodynastic period IIIa, i.e. 26002450 BCE.

2 According to Chrobak (2013), the list contains representatives of various professions working in a temple. The "interpreter" comes after the "kingal" "the one standing above the others" (the overseer) and the "sag-du" or "head of cadaster".

3 Chamberlain, overseer and treasurer of Pharaoh Akhenaten who died c. 1360 BCE.

4 Harkuf, a native of Elephantine, was a governor of the southern part of Upper Egypt, serving under the reign of King Merenre and King Pepi II, third and fourth king of the 6th dynasty, respectively. His primary business was trade with Nubia. His life is known entirely from the inscriptions in his tomb at Aswan, near the First Cataract of the Nile.

5 Egyptian Emperor (595 BCE - 589 BCE).

6 Roman statesman and military commander. 
7 Greek statesman and historian. He wrote the Histories, a work consisting of 40 books, the last being indexes. Books I-V are extant. For the rest there are various excerpts. Polybius' original purpose was to narrate the history of the 53 years (220-168 BCE) — from Hannibal's Spanish campaign to the Battle of Pydna-during which Rome had made itself master of the world (Walbank, n.d.).

8 Inhabitants from the Trogodyte, near the middle Nile.

9 The term seems to have derived from "Hermes", the God of commerce who was a mediator for the Olympian Gods (Ringler, 1999).

10 Book 1, Chapter 19, where Caesar dismisses all interpreters except his most trusted interpreter, C. Valerius Troucillus.

11 Leo Tuscus was already invicti principis egregius interpres (interpreter of the invincible and distinguished prince) in 1166 and still imperialium epistolarum interpres (imperial epistolary interpreter) in 1182 (Haskins, 1918).

12 Jerusalem was one of the three great centres of pilgrimage, together with Rome and Santiago de Compostela.

13 Clausewitz (1832/1918) defines war as a sign of political and social behaviour - a violent means to achieve political or social goals that has existed since the beginning of human history. Sheehan (2008) adds that war is an event that is highly organised in itself, as well as an organizing force in its own right. This point is apt, given that even a cursory examination of armed conflict reveals it as a multidisciplinary exercise involving many roles and tasks. In fact, war is an organised event, and the whole concept of war and its stages follow a precise structure. In order to play their respective parts competently, all the participants in a conflict, including interpreters, need a clear understanding of the tasks expected of them and the skills required to perform them. 